\title{
Lesson Planning and Proactive Classroom Management Strategies for Teaching English at Tertiary Level in Pakistan
}

\author{
Ameer Ali \\ University of Sindh, Jamshoro, Pakistan \\ ameer7037@gmail.com
}

\section{ARTICLE HISTORY \\ Received : 17 December 2020 \\ Revised : 20 December 2020 \\ Accepted : 19 January 2021}

\section{KEYWORDS \\ Lesson Planning \\ Proactive Classroom \\ Management \\ Tertiary Level \\ Pakistan}

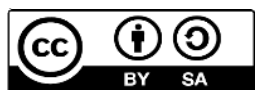

\begin{abstract}
There is scarcity of research on classroom management and lesson planning at tertiary level, so the current research investigates these dimensions at tertiary level in Pakistan's context. This research article is an investigative attempt of understanding lesson planning and proactive classroom management strategies for teaching English at tertiary level in Pakistan. In this regard, the current research analyses primary data collected from the research participants. Moreover, this research paper is qualitative, because it answers open-ended questions using cross-sectional survey as a data collection tool. The investigator has made use of purposive sampling for selecting research participants from different sections of Pakistan's tertiary level education institutions. The researcher has also employed thematic analysis method to study the collected data. The study reveals that many teachers set objectives, such presentation stage, production stage, and practice stage while planning their lessons. Similarly, the teachers at tertiary level employ behaviour and discussion-based strategies to bring forth proactive classroom management. These findings contribute to the understanding of educationists and bring about further research work at tertiary level from different dimensions. Overall, this research contributes to the pool of knowledge as a qualitative attempt of studying pedagogical management and planning at tertiary level.
\end{abstract}

\section{Introduction}

Lesson planning and pro-active classroom management are two important mechanisms of teaching English at tertiary level in Pakistan. Lesson planning is a process of setting objectives, activities, and timeline for imparting lessons in a classroom (Singapore Management University, 2020). According to Centre for Teaching Excellence at Singapore Management University (2020), a lesson plan serves as a road map for a teacher that guides him or her on what to teach and how to teach. Through lesson planning, an instructor can easily develop activities, strategies, and feedback to make his/her teaching much more effective (Derin et al., 2020; Batubara et al., 2020).

Moreover, learning objectives, activities, and assessment of students' understanding are the key components of a lesson plan (Mantra, Astawa, \& Handayani, 2019; Stauffer, 2019). An effective lesson plan carries out all these activities in three phases: before the class, during the class, and after the class (Singapore Management University, 2020). First, a teacher plans activities, sequence, and realistic timeline to be implemented in the class. Second, when the teacher enters his/her classroom, he/she shares the plan with students and tries to engage them and keep them on the track. Third, the teacher reflects on how things went on and what he could have done differently to get much better results.
Lesson planning also serves as a process which enables teachers to give a step-by-step structure to students' learning mechanisms (Juicy English, 2020). This blog identifies four stages of lesson planning which are introduction, development, consolidation, and conclusion. Much like lesson planning, proactive classroom management is also an essential part of effective teaching. The proactive management strategies help teacher control disruptive students of their class. Kounin \& Gump (1950), two psychologists, say that when teachers try to control disruptive students through harsh behaviour, it usually brings about ripple effect. The ripple effect implies the fact that much like a ripple, a teacher's harsh reaction to a student's disruption causes other students to be disruptive. This situation is very challenging for teachers. Most of the teachers are not trained to tackle these types of issues and consequently they end up losing much of their instructional time (Heiskell, 2020). This is exactly why teachers need proactive classroom management strategies to discipline their students and make their teaching much more influential.

Similarly, the issues of lesson planning and classroom management have been quite challenging for English language teachers and policy makers at tertiary level in Pakistan's educational institutions since the beginning. Most of the teachers cannot achieve their teaching objectives due to ineffective lesson planning and classroom management. This issue is badly impacting both students 
and teachers. Though some attempts have been made to solve this issue at tertiary level in Pakistan, but these efforts are not enough. Much more integrated, comprehensive training programmes and language policies should be introduced to equip teachers with sophisticated means of lesson planning and classroom management strategies (Khan, 2020). If this issue is not solved immediately, it would entail many more challenges for education, language, learning, teachers, and students.

Therefore, it is the aim of this research to find out the mechanisms of lesson planning at tertiary level in Pakistan. Also, it attempts to identify the effective strategies of proactive classroom management. Moreover, this research shows the manner of employing classroom management strategies at tertiary level in Pakistan. This research paper has addressed these research questions: (1) What lesson plan techniques are used in Pakistan at tertiary level? (2) How are these lesson plans devised and implemented in Pakistan at tertiary level? (3) What classroom management strategies are usually used at tertiary level in Pakistan? (4) How are these strategies implemented?

\section{Literature Review}

The author stressed that these studies showed the significance of lesson planning and proactive classroom management, however, none of the studies to the best of the author's knowledge mentioned or discussed lesson planning and proactive classroom management at tertiary level in Pakistan. Consequently, this research aims to fill the research vacuum by investigating lesson planning and proactive classroom management at tertiary level in Pakistan by collecting data through open-ended questionnaire.

Experience plays a vital role in planning a lesson. Cunado \& Abocejo (2018) say that if a teacher is much experienced, chances are that he/she will be an efficient lesson planner. Their research work is an investigative attempt in Philippines' context at tertiary level. They have studied the lesson planning competencies of second year university students. Using descriptive survey as a research design, the researchers have shown that the teachers are good at designing lesson plans due to their exposure to the related knowledge and experience. Similarly, training in lesson planning can develop the skills of novice teachers. Besides, the research also discovers the fact that through lesson planning competent teachers can become more efficient in achieving their teaching objectives. Thus, lesson planning is much important for true teaching and learning.

Gallego (2007) has approached lesson planning from design and preparation dimensions. Building upon these aspects of lesson planning, he demonstrates how teachers take context, goals, contents, strategies, and evaluation into consideration when planning their lessons. Building upon longitudinal, correlational study, Dorovolomo, Phan, \& Maebuta (2010) have shown that there is a positive relationship between the quality of lesson planning and the quality of delivery techniques. According to them effective delivery techniques rather than mere implementation make lesson planning effective. Drawing upon qualitative discussion Lynch \& Warner (2008) argue that an effective lesson plan must address individual variety and dispersion of skills among students. They are of the view that onesize-fits-all type of lesson planning is no longer effective, therefore teachers can do their best by taking the individual variety of students into consideration when making lesson plans (Lynch \& Warner, 2008).

Much like these research scholars, Fujii (2016) has also studied the mechanisms of lesson planning. The dimension that Fujii (2016) has taken is much interesting. This research scholar focuses the process, role, and function of lesson planning. Fujii (2016) wants to turn scholars' attention to these key components of lesson planning by drawing upon the case studies carried out by Tokyo Gakugei University. Moreover, this study also investigates the task, design, and the flow of lesson planning. It also offers suitable solutions to make lesson planning much more efficient. Thus, Fujii's research work (2016) makes key components of lesson planning visible to readers and concerned scholars.

Apart from the above key components, teachers' needs as well as students' needs also influence the mechanisms of a lesson plan. Both students and teachers express their needs which influence the planning of a lesson. There is a concept-based research paper in Indonesia's context which confirms the fact that the shared needs of both students and teachers influence the creation of a lesson plan (Saito et al., 2018). This research paper also deals with two key areas of a study plan. First, the subject-oriented area comes under the researchers' focus. Second, the researchers look at student-oriented aspect of a study plan. The research article makes use of comparative institutional analysis to investigate all these areas and needs. Hence, it tries to develop sophisticated concepts about lesson planning in Indonesia's context.

There is yet another research paper which has studied the impact of lesson planning on teaching capabilities of a teacher. The research work shows that if a teacher is oriented towards meaning or application, the lesson study would have many positive effects on his/her teaching (Vermunt et al., 2019). These meaning and application orientations contribute to the successful achievement of teaching goals and objectives. In contrast, lesson study is not effective with problem-oriented approach. Novice teachers having not much exposure to lesson planning are good with meaning-oriented approach, but they are not at home with problem-oriented teaching (Vermunt et al., 2019). Moreover, this research paper has made use of longitudinal, cross-sectional survey as a design. There were 214 research participants in the project which found out the above given facts. In short, the research paper has explored the meaning, application, and problem orientations of lesson planning. 
Classroom management strategies also contribute to effective teaching and learning. If a teacher manages effective behaviour and discussion in his/her class, this will contribute to proactiveness. Teachers can create positive environment in their classrooms by making use of different strategies (Ahmad, Hussin, \& Yusri, 2018; Nagler, 2016). The researcher has revealed that teachers often use motivation, reflection, and expectation as proactive strategies to engage their students and keep them on track. If teachers can successfully manage these strategies, they will have positive impact. On the other hand, if they fail to manage these strategies in their classrooms, they will have negative impact. Thus, it all depends on how teachers can manage these strategies.

Evertson \& Poole (2008) add to the traditional conception of proactive classroom management by qualitatively discussing a teacher's role inside classroom. They argue that proactive classroom management does not only imply behavior control or discipline, but also it includes a teacher's actions which he/she undertakes to facilitate academic and socio-emotional learning among students inside classroom (Evertson \& Poole, 2008).

Similarly, classroom management is also much more important for L2 teachers because their prospects of permanent teaching depend on it (Clara \& Solarte, 2018). Moreover, this research paper also describes different dimensions and approaches of classroom management. The researchers offer some insights for L2 teachers who can draw upon these ideas and ensure their permanence in the field of teaching (Clara \& Solarte, 2018). This research paper directly addresses the L2 teachers in the context of America. It is, therefore, no wrong to say that the paper is American-centric in its form and content. Though it is confined to America, but L2 teachers can draw upon its insights to develop their own contextualized understanding.

Classroom management strategies have direct relation with students' learning and anxiety. Learners can respond differently to the classroom management strategies employed by their teacher. In Iranian context, Marashi \& Asggar (2019) have carried out a quantitative study to understand the correlation between teachers' classroom management strategies and students' learning and anxiety. They included 750 students and 50 teachers in their research work. They found out that teachers' management strategies enhanced those students' learning who employed learning strategies. But their classroom management strategies could not work with those who had anxiety. Thus, they suggest that teachers must also reduce anxiety of their students' learning.

When it comes to managing the students with disabilities, the role of proactive classroom management becomes much more important. Teachers often struggle when they teach disable students. Gilmour, Majeika, Sheaffer, \& Wehby (2019) have studied this issue in a systematic manner. They have shown that most of the teacher evaluation rubrics have no components of evidencebased activities and students' misbehaviour (Gilmour et al, 2019). They suggest that these factors must be made part of both teacher evaluation rubrics as well as classroom management. They assert that this will make teaching effective even in case of the disable students. Thus, this instance also shows that classroom management is much important even when one is to teach disable students.

All the above research papers irrefutably stand by the fact that both lesson planning and proactive classroom strategies play a very vital role in teaching and learning of a language. Similarly, the current research attempts to find out the mechanisms of lesson planning and classroom management, so that effective English language instruction might be assessed and ensured at tertiary level in Pakistan. Finally, this research is a qualitative, cross-sectional survey of Pakistan's tertiary level education institutions.

\section{Method}

This is empirical, qualitative research paper. It contains open ended survey questionnaire as a data collection tool. The researcher chose open ended questionnaire because it helps in gaining in depth data, and it also helps the researcher in anchoring to the related protocol (Creswell, 2012).

The researcher used purposive sampling and crosssectional survey questionnaire for selecting research participants from Pakistan's tertiary level education institutions. The researcher selected the participants irrespective of gender, caste, ethnicity, sect, and religion to ensure impartiality (Creswell, 2012). Moreover, the researcher sent eight open-ended questions to 10 (ten) research participants through email due to Covid-19 situation and their names were not mentioned in this as a matter of confidentiality. The researcher analysed the results with thematic analysis.

\section{Results \& Discussion}

In this section, the researcher has systematically conducted thematic analysis of the primary data.

\subsection{Lesson Planning at Tertiary Level in Pakistan's Educational Institutions}

The researcher discussed the results of the open ended questionnaire with thematic analysis. Table 1 displays each lesson stages, the factors, manner of implementation, reflection procedure, and level of education. 
Table 1. Research Findings on Lesson Plan Stages

\begin{tabular}{|c|c|c|c|c|c|}
\hline Participants & Lesson Plan Stages & $\begin{array}{c}\text { Factors } \\
\text { determining } \\
\text { activities }\end{array}$ & $\begin{array}{l}\text { The manner of } \\
\text { implementation }\end{array}$ & $\begin{array}{l}\text { The Procedure } \\
\text { of Reflection }\end{array}$ & $\begin{array}{l}\text { The Level } \\
\text { of } \\
\text { Education }\end{array}$ \\
\hline Participant 1 & Situational design & $\begin{array}{l}\text { Response } \\
\text { concern }\end{array}$ & $\begin{array}{l}\text { Course outline } \\
\text { announcement }\end{array}$ & $\begin{array}{l}\text { Inclusion of } \\
\text { technology }\end{array}$ & Tertiary \\
\hline \multirow[t]{2}{*}{ Participant 2} & $\begin{array}{l}\text { Presentation, } \\
\text { practice, }\end{array}$ & $\begin{array}{l}\text { Students' } \\
\text { learning needs }\end{array}$ & $\begin{array}{l}\text { Sharing lesson } \\
\text { plan and timeline }\end{array}$ & $\begin{array}{l}\text { Improvement } \\
\text { oriented }\end{array}$ & Tertiary \\
\hline & production & & & & \\
\hline Participant 3 & $\begin{array}{l}\text { Pre-planning and } \\
\text { post-planning }\end{array}$ & Syllabus contents & Motivation & $\begin{array}{l}\text { Experience and } \\
\text { insights }\end{array}$ & Tertiary \\
\hline Participant 4 & Pre-planning only & Students' interest & $\begin{array}{l}\text { Tactical use of } \\
\text { strictness }\end{array}$ & $\begin{array}{l}\text { Avoiding } \\
\text { unfavourable } \\
\text { incidents }\end{array}$ & Tertiary \\
\hline Participant 5 & Planned lessons & Consultation & Punctuality & $\begin{array}{l}\text { Temporal } \\
\text { management }\end{array}$ & Tertiary \\
\hline
\end{tabular}

\section{Item 1. What are the basic stages of your lesson planning?}

This question item asked about the stages used in lesson planning at tertiary level in Pakistan by English language teachers.

"I try to design the lesson plan that befits the nature and level of my students. I get them involved in interactive activities and such sorts of things."

\section{Excerpt from Participant 1}

"I always plan my lesson in three stages: presentation, practice, and production.”

\section{Excerpt from Participant 2}

"My basic stages of lesson planning are pre-class planning, and post-class planning."

Excerpt from Participant 3

"I plan lesson once before I go for a class. That's it."

Excerpt from Participant 4

"In my case, I follow the same old lesson plans."

\section{Excerpt from Participant 5}

The above given responses show that different teachers have different ways of planning their lessons. There are also teachers who read particular situations and develop their lesson plans accordingly. The participant 1, a teacher at tertiary level, says that his lesson plans are situational in their form and content. He uses historical contents to teach language and thus develops an efficacious lesson plan. Besides, there are also some teachers who divide their lesson plans in different stages. The participant 2, an English language teacher at a private university, says that she often distributes her lesson plans in what experts at
Singapore Management University (2020) define as presentation, practice, and production stages. This division of lesson plans into three stages is also an influential way of designing teaching goals and objectives. While other teachers employ both pre-planning and post-planning to design their lessons. The participant 3 does both preplanning and post-planning to improve his lesson designing skills. Likewise, the participant 4 prefers doing preplanning. The participant 5 only follows already planned lessons. Thus, different teachers have different ways of planning their lessons at tertiary level in Pakistan.

Item 2. What makes you choose specific activities for your students?

This question item asked about the different activities used by language teachers at tertiary level in Pakistan.

"Because if I do not decide activities for my students, they will get bored and certainly the response rate will be decreased."

Excerpt from Participant 1

"Students' specific learning needs help me a lot in choosing classroom activities."

Excerpt from Participant 2

"I look at the syllabus and then I decide the content specific activities."

Excerpt from Participant 3

"I involve my students and make them do what they find interesting."

Excerpt from Participant 4

"I consult with my colleagues and this sorts out my problems."

Excerpt from Participant 5 
Much like lesson plan development, teachers at tertiary level in Pakistan have different concerns in designing classroom activities to achieve their teaching objectives. Eliciting responses from students also makes teachers include suitable language teaching activities in their lesson plans. The participant 1 says that his decisions of including classroom activities in his lesson plans are determined by the fact that these activities will enable students to participate and respond to the learning requirements. Furthermore, students' learning needs also help teachers in choosing specific classroom activities. The participant 2 points out that first she takes into consideration the learning needs of her students and then accordingly chooses specific activities for her students. This type of consideration indeed improves students' learning and performance, and it also dovetails with what Lynch and Warner (2008) defined as a teacher's capability of dealing with students' dispersion of skills. Similarly, teachers also allow students to decide specific activities which cater to their needs and interests. In contrast, there are some teachers who only consult with their colleagues and choose certain activities which at times become difficult to implement, because these borrowed activities are not based upon evidence and they have no place in teachers' evaluation rubrics as discussed by Gilmour et al (2020). In this way, teachers follow their own insights and experiences in designing or choosing classroom activities.

\section{Item 3. How do you implement your lesson plan in the classroom?}

This question item asked about how language teachers at tertiary level in Pakistan implement lesson plans in their classrooms.

"First of all, I announce the outline before them in the preliminary class. I clarify the going across the semester. I allot them certain tasks that keep them engaged throughout. Thus, I find the class students more enthusiastic and working."

\section{Excerpt from Participant 1}

"I share my lesson plan with students, and I follow timeline, and keep my students on the track."

\section{Excerpt from Participant 2}

"I create positive environment through motivation, and then go on with usual way of teaching and implementing my lesson plan."

\section{Excerpt from Participant 3}

"Sometimes, strictness does the job, and I like to use it tactically."

Excerpt from Participant 4

"I try to finish everything on time."

Excerpt from Participant 5
Similarly, there are different ways of lesson plan implementation in Pakistan at tertiary level. Some teachers announce in advance what they will be doing throughout the course duration. The participant 1 usually announces the course outline in advance which he believes will keep students on track and make lesson plan implementation much easier. This announcement of course outline is like the techniques discussed in Dorovolomo, Phan, and Maebuta (2010) which makes lesson implementation effective. Similarly, the participant 2 also shares her lesson plan with students and follows time sequence in implementing her lesson plan. Moreover, other teachers tend to make use of encouragement as a tool of implementing their lesson plans. The participant 3 reveals that it is through motivation that he implements his lesson plans. Motivation is indeed an effective tool of lesson implementation and management as shown by Nagler (2016). In contrast, there are also those teachers who make tactful use of strictness to implement their lesson plans. The participant 4 is one of them. She makes a tactical use of strictness to achieve her lesson objectives and implement her lesson plans. The use of strictness even at tertiary level does play a vital role in implementing class lesson plans. In short, there is no uniformity in the manner of implementing a lesson plan.

\section{Item 4. How do you reflect on your lesson plan?}

This question item asked about the language teachers' reflective activities.

"Personally, I think it is fine for the current batches. However, with the passage of time I will need to design lesson plans as per technology-oriented sources as that is going to be the reality of tomorrow's world."

Excerpt from Participant 1

"After taking class, I often think what went well and what I could have done to make my teaching much better. That's how I reflect on my lesson plan."

Excerpt from Participant 2

"My much more experienced colleagues help me reflect over my teaching mechanisms. It's through their experience and my own insights that I manage to reflect effectively."

Excerpt from Participant 3

"I mostly reflect on an unfavorable event which happens, and I try to figure out why it happened and what could have been done to avoid it."

Excerpt from Participant 4

"My reflection goes to the way I manage time of my lesson plan, and I tend to reflect temporally."

Excerpt from Participant 5 
In summary, the given responses show that teachers do reflect after their class. Reflection is a crucial component of teaching as discussed in Nagler (2016). They either seek to improvise their performance or try to avoid undesired incidents in their classes caused by conservative teaching mindset as discussed by Simangunsong (2020). Thus, they effectively reflect on their lesson plans and their implementation.

\subsection{Proactive Classroom Management Strategies at Tertiary Level in Pakistan}

This study also found out about different proactive classroom management strategies at tertiary level in Pakistan used by English language teachers. Table 2 summarised the teachers' strategies to manage classroom disruptions and students who are reserved, along with how frequently they evaluate their strategies, their judgment on their students' reactions and educational level.

Table 2. Research Findings on Proactive Classroom Management Strategies

\begin{tabular}{|c|c|c|c|c|c|}
\hline $\begin{array}{c}\text { Research } \\
\text { Participants }\end{array}$ & $\begin{array}{l}\text { Management } \\
\text { of Disruption }\end{array}$ & $\begin{array}{l}\text { Managing } \\
\text { Reserved } \\
\text { Students }\end{array}$ & $\begin{array}{l}\text { Evaluative } \\
\text { Frequency of } \\
\text { Classroom } \\
\text { Management } \\
\text { Strategies }\end{array}$ & $\begin{array}{l}\text { Students' } \\
\text { Reaction }\end{array}$ & $\begin{array}{c}\text { Educational } \\
\text { Level }\end{array}$ \\
\hline Participant 6 & $\begin{array}{l}\text { Surprise } \\
\text { graded test }\end{array}$ & Friendliness & Monthly & Positive & Tertiary \\
\hline Participant 7 & $\begin{array}{l}\text { Good } \\
\text { behaviour }\end{array}$ & Making pairs & Regularly & $\begin{array}{l}\text { Disruptive } \\
\text { and } \\
\text { appreciative }\end{array}$ & Tertiary \\
\hline Participant 8 & $\begin{array}{l}\text { Reminders and } \\
\text { cues }\end{array}$ & $\begin{array}{l}\text { Asking direct } \\
\text { questions }\end{array}$ & On need basis & Situational & Tertiary \\
\hline Participant 9 & $\begin{array}{l}\text { Optimal } \\
\text { seating plan }\end{array}$ & $\begin{array}{l}\text { Participation } \\
\text { marks }\end{array}$ & $\begin{array}{l}\text { Always after } \\
\text { class }\end{array}$ & Disciplined & Tertiary \\
\hline Participant 10 & $\begin{array}{l}\text { Active } \\
\text { supervision }\end{array}$ & $\begin{array}{l}\text { Assigning } \\
\text { responsibilities }\end{array}$ & Rarely & Compliant & Tertiary \\
\hline
\end{tabular}

\section{Item 5. What strategies do you use to discipline your disruptive students?}

This question item asked the English language teachers to demonstrate what strategies they use to manage their disruptive students.

"I suddenly announce the surprise graded test so as to get them attentive and this way they happen to be instantly inclined towards the track."

\section{Excerpt from Participant 6}

"I use good behaviour as a strategy to control my disruptive students."

\section{Excerpt from Participant 7}

"Managing disruptive students is a very challenging task. It takes time and efforts. I use reminders and cues to help them realize that what I am teaching them is much important for their future."

\section{Excerpt from Participant 8}

"Disruption never goes away. It comes back in different forms and shapes. So, I separate disturbing students from one another, and it temporarily silences them."
Excerpt from Participant 9

"I have to supervise actively to discipline these students."

Excerpt from Participant 10

Apart from lesson planning, teachers also engage in different ways of proactive classroom management strategies to control their disruptive students. Teachers make use of surprise tests to discipline these types of students. The participant 6 , a teaching assistant, tends to employ surprise grading tests as a tool to control disruption in her class. Moreover, the strategy of good behaviour also helps teachers in disciplining disruptive students. The participant 6 , an experienced teacher, says that he proactively plans good behaviour as a strategy to check his students' disturbing behaviour. Also, reminders and cues towards final examinations serve as effective, proactive strategies to control disturbing students. The participant 8 , a novice teacher, uses cues and reminders as a proactive strategy to tackle her students' disruptive behaviour. While optimal seating plan, as used by the participant 9 also helps in checking disruption. Additionally, the participant's (10) proactive strategy of active supervision allows students no chance of channelling their disruption. All these proactive 
strategies enable teachers to facilitate their students in learning what Evertson and Poole (2008) defined as academic, and socio-emotional knowledge. Hence, proactive strategies are quite helpful in disciplining disruptive students.

\section{Item 6. How do you make your reserved students speak?}

This question item asked the ways language teachers use to engage their reserved students.

"I embrace for them a dialogic way where I go between them and treat them as my friends and encourage them in a special manner to justify their presence."

\section{Excerpt from Participant 6}

"I make pairs of students and thus engage them in discussing different topics."

\section{Excerpt from Participant 7}

"It's not an easy task to do so, but I put a direct question to them, and they start participating."

\section{Excerpt from Participant 8}

"I keep class participation marks. Then I announce that I will give marks to those students who will participate in my class. That's how I make them speak."

\section{Excerpt from Participant 9}

"I give them some class responsibilities and they are no more reserved."

Excerpt from Participant 10

Dealing with reserved students has always been a difficult task to do, and language teachers at tertiary level have been trying proactively to manage these types of students. There are teachers who establish closeness with reserved students to make them speak or participate in the class. The participant 6 befriends the reserved students and make them feel comfortable during the class. Besides, allowing reserved students to work in pairs also helps them. The participant 7 does the pairing of his reserved students with much more active students, and it really helps the former. Additionally, the participant 8 uses direct questions as a proactive strategy to make these types of students speak in the class. Direct questioning is an effective tool of eliciting response from the reserved students in the class. The other type of proactive strategy for managing reserved students is to assign marks for class participation. The participant 9 uses this strategy to manage the reserved students. The participant 10 assigns them responsibilities which make them active. These proactive strategies reduce the anxiety of the reserved students as discussed in Marashi and Asggar (2019).
Item 7. How often do you evaluate your proactive classroom management strategies?

The researcher assessed the frequency of language teachers' evaluation of their proactive classroom management strategies.

"After every month, I happen to evaluate the classroom management activities and then I refine them accordingly."

Excerpt from Participant 6

"I do this on regular basis."

Excerpt from Participant 7

"Whenever there is need of doing so, I just do it."

Excerpt from Participant 8

\begin{abstract}
"After taking my class, I always evaluate how well I managed my class and what else I could do to make it much better."
\end{abstract}

Excerpt from Participant 9

"To tell you honestly, I rarely do that."

Excerpt from Participant 10

The above given table and responses show that teachers do evaluate their proactive classroom management strategies. Some of them do it regularly, while others do it weekly or monthly. There are still other teachers who rarely evaluate their proactive classroom management strategies to make their teaching and classroom management influential as suggested by Gallego (2007).

Item 8. What is the usual reaction of your students when you try to manage their disruption?

Here, I have discussed students' responses to their teachers' proactive strategies by interpreting the latter's responses.

"They primarily take it lightly but when I intensify my pace by introducing some pertinent topic, they get back to the lane."

Excerpt from Participant 6

"If I treat them harshly, they become disruptive. On the other hand, if I befriend them, they become less disruptive."

Excerpt from Participant 7

"It varies from one student to another. Some take it serious and adopt discipline, while others pay no heed at all."

Excerpt from Participant 8 
"Students usually show discipline."

\section{Excerpt from Participant 9}

"Students at this level are mostly mature, so they like to comply with what I say or do with them."

\section{Excerpt from Participant 10}

When asked about the students' response to their proactive strategies, the teachers have given different answers. The experience varies from one teacher to another in the same way as it varies from one student to another student. Speaking generally, some teachers say that students usually react harshly if a teacher tries to discipline their disruption with harshness. While other teachers say that their students are mature at this level and they usually comply with their instructions. Thus, the response differs in accordance with a different situation.

Lesson planning plays an effective part in teaching language at tertiary level in Pakistan. Through lesson planning, teachers are able to devise their pedagogical goals and plans. Moreover, lesson planning also facilitates teachers with an opportunity of systematically dividing their teaching into different stages which makes teaching, evaluation and reflection much more convenient for language and other subject teachers at tertiary level in Pakistan.

In addition to lesson planning, proactive classroom management also plays a vital role in making teaching and learning effective at tertiary level in Pakistan. Using proactive strategies in their classes allows Pakistani teachers to uplift their teaching skills and groom their personalities. Moreover, these strategies also enhance the teachers' prospects of permanent teaching as discussed by Clara \& Solarte (2018).

\section{Conclusion}

There are different ways of planning, implementing, and reflecting on a lesson plan. Similarly, different teachers employ different proactive classroom management strategies to ensure engagement and achieve their teaching objectives. If teachers in Pakistan at tertiary level start evaluating their lesson plans and classroom management strategies on regular basis, this would uplift the country's education standards. This is indeed the right time of start doing that. If it is delayed, the education system will entangle into many more problems.

This research will encourage researchers to carry out more research work in the area of lesson planning and proactive classroom management in the context of different subjects at tertiary level in Pakistan. Furthermore, this research work will also encourage stakeholders in the education sector to make effective use of lesson planning and proactive strategies to improve their teaching and enhance students' learning process. The effective teaching through planning and strategies will create great members of our society who will be able to solve our society's multifaceted problems and thereby will become good members of the society.

\section{References}

Ahmad, T., Hussin, A., \& Yusri, G. (2018). Discovering students' preference for grammar learning activities outside the classroom. Journal of Creative Practices in Language Learning and Teaching, 6(2), 60-71.

Batubara, F., Derin, T., Putri, N. S., \& Yudar, R. S. (2020). Five Factors Influencing the Students' Motivation to Learn English as a Foreign Language: A Closer Look into Montessori Classroom Environment. REiLA: Journal of Research and Innovation in Language, 2(2), 76-84.

Creswell, J. W. (2012). Educational research: Planning, conducting, and evaluating quantitative and qualitative research (4th ed.). Boston, MA: Pearson.

Cuñado, A., \& Abocejo, F. T. (2018). (PDF) Lesson planning competency of English major University sophomore students. European Journal of Education Studies 5(8).

Derin, T., Susilo Putri, N., Nursafira, M. S., \& Hamuddin, B. (2020). Discourse Analysis (DA) in the Context of English as a Foreign Language (EFL): A Chronological Review . Elsya : Journal of English Language Studies, 2(1), 1-8 https://doi.org/10.31849/elsya.v2i1.3611

Dorovolomo, J., Phan, H. P., \& Maebuta, J. (2010). (PDF) Quality lesson planning and quality delivery: Do they relate? University of the South Pacific: Suva, Fijii. Retrieved January 16, 2021, from https://www.researchgate.net/publication/287061517 _Quality_lesson_planning_and_quality_delivery_Do _they_relate.

English, J. (2020, 16 February). Apply these 4 stages in your lesson planning. Juicy English. https://www.juicyenglish.com/blog/lesson-planning4-stages-for-effective-lesson-planning.

Evertson, C. M., \& Poole, I. (2008). Proactive classroom management. In T. Good (Ed.), $21^{\text {st }}$ Century education: a reference handbook. Thousand Oaks, CA: SAGE Publications Inc. https://doi.org/10.4135/9781412964012.n14.

Fujii1, T. (2016). Designing and adapting tasks in lesson planning: a critical process of Lesson Study. ZDM Mathematics Education.

Gallego, M. R. (2007). (PDF) Lesson planning in primary and secondary education. Technical Report. Retrieved January 16, 2021, from https://www.researchgate.net/publication/269463679 
_Lesson_planning_in_Primary_and_Secondary_Edu cation.

Gilmour, A. F., Majeika, C. E., $\quad$ Sheaffer, A. W., \& Wehby, J. H. (2019). The coverage of classroom management in teacher evaluation rubrics. Eric 42(2) https://journals.sagepub.com/doi/abs/10.1177/08884 06418781918.

Khan, M. A. A. (2020). Analysis of EFL Teaching in Pakistan: Method and Strategies in the Postmethod Era. REiLA : Journal of Research and Innovation in Language, 2(3), 93-100. https://doi.org/10.31849/reila.v2i3.4802

Lynch, S. A., \& Warner, L. (2008). Creating lesson plans for all learners. Kappa Delta Pi Record 45(1). https://www.researchgate.net/publication/234558276 _Creating_Lesson_Plans_for_All_Learners.

Mantra, I. B. N., Astawa, I. N., \& Handayani, N. D. (2019). Usability of innovative learning models in higher education. International Journal of Social Sciences, 2(1), 38-43.

Marashi, H., Assgar, F. (2019). EFL Teachers' Effective Classroom Management and Learners' Anxiety and Learning Strategie. Iranian Journal of Language Teaching Research.

Saito, E., Hang Khong, T. D., Hidayat, A., Hendayana, S., \& Imansyah, H. (2018). Typologies of lesson study coordination: A comparative institutional analysis. Professional Development in Education 46(1). https://www.tandfonline.com/doi/abs/10.1080/19415 257.2018.1561495.

Sieberer-Nagler, K. (2016). Effective ClassroomManagement \& Positive Teaching . English Language Teaching.

Simangunsong, W. (2020). A Closer Look at Junior High School English Teachers in Pekanbaru: Does the Reluctance of Teachers to Adapt with ICT Hindering English Learning? . Elsya : Journal of English Language Studies, 1(3), 74-80. https://doi.org/10.31849/elsya.v1i3.4999.

Solarte, A. C. (2016). Classroom Management and Novice Language Teachers: Friend or Foe? HOW.

Stauffer, B. (2019). What is a lesson plan and how do you make one? Retrieved January 16, 2021, from https://www.aeseducation.com/blog/what-is-alesson-plan.

Vermunt, J. D., Vrikki, M., van Halem, N., Warwick, P., \& Mercer, N. (2019). The impact of Lesson Study professional development on the quality of teacher learning. Teaching and Teacher Education, 81, 6173. https://doi.org/10.1016/j.tate.2019.02.009 